\title{
10 anos da crise financeira (2008-2018): Leituras e interpretações
}

\author{
Roberto Goulart Menezes ${ }^{3}$ \\ Leonardo Ramos ${ }^{4}$
}

DOI: $10.5752 /$ P. 1809-6182.2018v15.n2.pl

Em setembro de 2008, a falência do banco Lehman Brothers desencadeou uma sucessão em cadeia de quebras na economia dos Estados Unidos da América. O então presidente, George W. Bush (2002-2009), estava em final de mandato e relutou em intervir na economia para tentar conter a quebra do Lehman. No entanto, a situação crítica da AIG, entáo a maior seguradora do mundo, com ativos de cerca de US\$ 1 trilhão, forçou o governo estadunidense a descruzar os braços e agir. A medida em que as informações iam se avolumando não restava mais dúvidas: a crise financeira não estava circunscrita aos EUA. Em poucas semanas ela se espalhou pelo mundo atingindo em cheio a Europa e colocando o Euro à prova. Essa turbulência varreu o globo.

Em janeiro de 2009, Barack Obama assumiu a presidência dos EUA no pior momento da crise financeira. O consenso neoliberal estava sob forte contestaçấo, pois na raiz da maior crise financeira do capitalismo histórico, estavam as inovaçooes financeiras introduzidas nas gestóes do ex-presidente republicano Ronald Reagan (1981-1989) que promoveram uma profunda desregulamentação dos mercados financeiros. Porém, os democratas também deram continuidade ao processo de soltar os freios dos mercados: em novembro de 1999 a Lei
Glass-Steagall de 1933, que regulava a emissão de títulos por bancos comerciais, fora revogada no governo do ex-presidente Bill Clinton (1993-2002). Pela Lei de 1933, a mesma empresa não poderia emprestar dinheiro e vender títulos mobiliários. Separava bancos comerciais dos bancos de investimento. Uma década depois o fim desse dique contribuiu decisivamente para a bancarrota.

No entanto, a crise do capitalismo neoliberal em 2008 bem como a contestação dos "princípios e práticas básicos da globalização neoliberal" (DUMENIL; LEVY, 2014, p. 12), não provocaram ainda mudanças significativas na direção de uma mundo pós-neoliberal. O retorno do Estado, ou melhor, a volta de sua legitimidade como ator econômico ocorreu através das políticas adotadas justamente para resguardar e recompor o patrimônio dos grandes bancos e seguradoras. De acordo com Blyth (2017) "o custo do resgate, da recapitalização e de outras formas de salvação do sistema bancário global [...], dependendo do modo como se contar, entre US\$ 3 e US\$ 13" trilhôes" (p. 26).

$\mathrm{Na}$ Europa a situação econômica da Grécia tornou-se emblemática: o endividamento do país desproporcional a sua capacidade de pagamento fez com que o governo grego recorresse à União Europeia

\footnotetext{
3. Professor Associado ao Instituto de Relaçôes Internacionais, Universidade de Brasília (UnB). ORCID: 0000-0002-3220-7765

4. Professor de Relaçôes Internacionais, Departamento de Relaçôes Internacionais da Pontifícia Universidade Católica de Minas Gerais (PUC-Minas). ORCID: 0000-0001-8245-6498
} 
(UE). Contudo, os gregos tiveram que implementar um pacote de austeridade como condição para receber recursos financeiros da UE. Essas condicionalidades impostas pela troika (Banco Central Europeu, Fundo Monetário Internacional e a Comissão Europeia), agravaram ainda mais a crise naquele país. A instabilidade política foi agravada pelas medidas impopulares impostas pela troika. A democracia grega estava agora tutelada pelos credores e assim a soberania popular pouco conseguia mudar essa realidade.

A crise mais profunda da economia mundial desde 1929 exigia mudanças na governança financeira. Porém, o alcance e as mudanças realizadas nos sistemas monetário e financeiro praticamente não alteraram a realidade pré-crise. Considerando que o sistema monetário é assimétrico e hierárquico, no qual os países centrais detêm a liderança, em especial os Estados Unidos, detentor da moeda-chave, o dólar, as reformas foram a conta gotas. O privilégio exorbitante dos EUA, ou seja, a senhoriagem exercida por eles em função do dólar ser a moeda-chave do sistema monetário foi central neste momento (EICHENGREEN, 2014). A reativação do G-20 financeiro em 2009 (que havia sido criado em 1999 após as crises na Ásia), tornou-se o principal espaço para se discutir as reformas necessárias a criação de uma nova governança, embora com o tempo pouco tenha contribuído para a construção de mudanças significativas na governança econômica global.

Neste processo, a crise de 2008 reforçou a multipolaridade nas relações internacionais. A criação dos BRICS como uma coalizão para coordenar as posiçóes nas discussóes sobre a reforma no FMI estendeu-se em partes para o G-20 financeiro, influenciando de maneira significativa muitas das discussóes e decisões adotadas neste fórum. Além disso, tal coalizão expressa algo fundamental que ocorre na esteira da crise: a saber, a afirmação da China como potência econômica e comercial, que desde 2009 é a segunda economia do mundo.
Neste contexto, reflexóes acerca dos aspectos relativos a tais transformação e mudanças são uma tarefa central, e é com este intuito que apresentamos o presente dossiê. Assim, discussóes acerca dos possíveis aspectos da transição na ordem mundial contemporânea são apresentados, com destaque para o papel da China neste processo e suas relações com os Estados Unidos em uma perspectiva mais ampla - vide os textos de Fernanda de Castro Brandão Martins e Carlos Frederico Pereira da Silva Gama \& Fernando Furquim de Camargo. Em termos mais específicos, Tom Claudino dos Santos, Ana Tereza Lopes Marra de Souza \& William Daldegan Freitas, Bruno Haeming e Débora Ramires Pelisson trazem reflexóes ricas e complementares acerca dos aspectos monetários da crise, suas consequências e possíveis desdobramentos. Atenção especial neste caso é dada ao papel do Renminbi neste contexto pós-crise. Além disso, Débora Ramires Pelisson e Renato Saraiva \& Thaís Dutra Fernández destacam a importância das dinâmicas espaciais neste contexto de (pós-)crise, particularmente dos arranjos regionais em uma perspectiva mais ampla. Por fim, temos a honra de contar com a traduçáo da resenha do livro de Adam Tooze, elaborada por Robert Kuttner. Neste sentido, agradecemos mais uma vez a autorização dada pelo editor do The New York Review of Books, Patrick Hederman. Em suma, esperamos com este dossiê possa contribuir para a continuidade e aprofundamento dos debates relativos à crise e suas consequências para ordem econômica mundial.

\section{Referências}

BLYTH, M. Austeridade: a história de uma ideia perigosa. São Paulo: Autonomia Literária, 2017.

DUMENIL, G.; LEVY, D. A Crise do neoliberalismo. São Paulo: Boitempo, 2014.

EICHENGREEN, B. Privilégio exorbitante. Rio de Janeiro: Campus, 2014. 